\title{
HUDAN LIN-NAAS
}

Jurnal Ilmu Sosial dan Humaniora

Volume: 2, no 1, Januari-Juni 2021

ISSN: 2580-3409 (Print), 2580-3972 (Online)

http://ejournal.idia.ac.id/index.php/hudanlinnaas/index

\section{HADIS DA'IF DAN MAWDU' DALAM KITAB NASA'IH AL-'IBAD OLEH NAWAWI BANTEN : \\ ANALISA TERHADAP KONTEN HADIS}

\author{
Arwansyah bin Kirin ${ }^{1}$, Siti Marpuah² Muhammad Masruri ${ }^{3}$ \\ 1,2,3Dosen di Jabatan Pengajian Islam, Pusat Pengajian Umum dan Kokurikulum \\ Universiti Tun Hussein Onn Malaysia \\ arwansyah@uthm.edu.my
}

\begin{abstract}
Abstrak
Kitab Nasa'ih al-'Ibad yang dikarang oleh sheikh Nawawi al-Banteni merupakan kitab klasik yang mengandungi aspek Targhib wa Tarhib. Kitab ini cukup terkenal di Nusantara khususnya Indonesia, karena ianya banyak dipelajari di pondok-pondok pesantren baik itu yang klasik maupun modren hingga ke hari ini. Sheikh Nawawi al-Banteni banyak menggunakan hadis-hadis Nabi SAW sebagai sumber utama dan argumen (hujjah) dalam kitab tersebut. Beliau juga memasukkan beberapa kategori hadishadis di antaranya adalah hadis Da'if dan Mawdu'. Permasalahannya adalah kitab ini mengandungi banyak hadis Da'if dan Mawdu' yang menjadi referensi dan panduan amal sehari-hari bagi umat Islam. Kajian ini amat penting untuk memahami aturan beramal dengan hadis Da'if dan Mawdu' terhadap umat Islam di Asia Tenggara khususnya Indonesia. Tujuan kajian ini adalah untuk menganalisis hadis-hadis Da'if dan Mawdu' yang terdapat dalam kitab Nasa'ih al-lbad mulai bab 5-10 sebagai sumber hukum. Metodologi kajian ini adalah kualitatif melalui kaedah kepustakaan dan reka bentuk analisis kandungan kitab Nasa'ih al-Ibad. Berdasarkan analisis yang dilakukan pada bab 5-10 dalam kitab ini, hanya 23.0 $\%$ yang dapat digunakan dalam Fada'il al-Amal sekiranya telah memenuhi beberapa syarat yang telah ditetapkan oleh para ulama. Oleh kerana itu, analisis tematik ini penting dilakukan untuk memastikan persentase hadis Da'if dan Mawdu' dalam kitab ini dan memastikan bahwa hadis Da'if ini dapat dipraktikkan hanya dalam Fada'il al-Amal. Status hadisnya penting bagi seorang Musliam sebagai sumber kedua dalam agama Islam.
\end{abstract}

Keyword : Hadis Da'if, Hadit Mawdu', Analisis, Nawawi al-Banteni, Asia tenggara

\section{Abstract}

The book of Nasa'ih al-Ibad by sheikh Nawawi al-Banteni is a classic book containing aspects of Targhib wa Tarhib, which is widely distributed in Southeast Asia, especially in Indonesia and it is widely used in pesantran and pondok today. Sheikh Nawawi al-Banteni refers much to the Prophet's hadiths 
as a main sources and evidences to argument that he mentions in her book. The problem with this book contains unknown status of hadith and which are became a daily reference and practice for the Muslim community. This study is very important to understand the ruling of practice with the Hadith Da'if and Mawdu' for the Muslim community in Southeast Asia. The objective of this study is to analyses the status of hadith in chapter 5-10 either as sources of ruling. The methodology used is content analysis from the Nasa'ih al-'Ibad book, while analyzing the study data using inductive methods. Based on analysis done on chapter $5-10$ in the book, only $23.0 \%$ of hadith can be used in Fada'il al-Amal, when it has met certain requirements set by scholars. Therefore, this thematic analysis is importance to ensure the percentage Hadith Da'if and Mawdu and the ruling of hadith Da'if can be practiced is only for Fada'il al-'Amal. The status of hadith is importance to Muslim as second sources of Islam.

Keywords: Hadith Da'if, Hadith Mawdu', analysis, Nawawi al-Banteni, Southeast Asia.

\section{Pendahuluan}

Dalam dunia Islam terutama di wilayah Nusantara sangat kaya dengan alim ulama, ilmuan, cendekiawan dan intelektual dalam pelbagai bidang. Sumbangan mereka dalam ilmu pengetahuan sangat besar terutama bagi umat Islam dari dulu hingga sekarang sehingga dapat menyuburkan suasana pengajian ilmu di Nusantara ini. Diantaranya yang terkenal ialah Syeikh Nawawi al-Banteni nama aslinya adalah Muhammad bin 'Umar bin 'Arabi bin 'Ali. Beliau terkenal dengan nama Muhammad Nawawi Sheikh al-Jawi al-Banteni' ${ }^{1}$. Di Indonesia beliau dikenali dengan panggilan K.H Nawawi Putra Banten². Sheikh Nawawi dilahirkan pada tahun 1230 H/1813 M di kampung Tanara, Serang, Kecamatan Tirtayasa Kabupaten Banten, Jawa Barat Indonesia ${ }^{3}$ dan wafat ketika berumur 84 tahun, yaitu pada tanggal 24 Syawal 1314 H/1897 M di tempat tinggalnya yang terakhir di Shi'ib 'Ali Makkah4. Nawawi al-Banteni adalah seorang tokoh ulama terkemuka, yang dipuji oleh Snouck Hurgronje sebagai penduduk setempat yang sangat rendah hati, seorang ilmuan pada masanya, dan penulis yang produktif dalam berbagai disiplin ilmu. Bahkan hari ini, banyak bukunya dipelajari di pesantren Indonesia dan wilayah Nusantara lainnya.

\footnotetext{
1 Yusuf 'Allan Sarkis, t.th, Mu'jam al-Matbu'ah al-'Arabiyyah wa al-Mu'arrabah, hlm. 1881, al-Qahirah : Maktabah al-Thaqafah al-Diniyyah.

2 Karel, S.A, 1984, Beberapa Aspek Tentang Islam di Indonesia Abad ke 19, hlm. 117, Jakarta : Terjemahan Bulan Bintang.

3 Chaidar, 1978, Sejarah Pujangga Islam Shaykh Nawawi Banteni, hlm. 5, Jakarta : CV Sarana Utama, 1978, hlm. 5 .

${ }^{4}$ Rafi'uddin Ramli, t.th, Sejarah Hidup dan Silsilah Keturunan Shaykh Nawawi Banteni, hlm. 7, Banten : Yayasan Nawawi Tanara.
} 


\section{Sorotan Literature Penulis Buku}

\subsection{Tinjauan Umum Tentang Penulis Buku : Sheikh Nawawi al-Bantani}

Menurut satu sumber, Sheikh Nawawi telah berjaya menghasilkan 99 buah karya tulis, manakala menurut sumber lain menyatakan bahawa hasil karya beliau mencapai 115 buah yang mencakupi pelbagai bidang disiplin ilmu5. Di Indonesia, karya-karya Sheikh Nawawi boleh didapati dipelbagai kedai buku yang ada di kotakota. ${ }^{6}$ Berdasarkan hasil penelitian yang dilakukan oleh Martin Van Bruinessen ke beberapa pesantren di Indonesia, bahwa Sheikh Nawawi menulis tidak kurang daripada 40 buku, ianya masih banyak diguna pakai sebagai materi pembelajaran di pesantren Indonesia. ${ }^{7}$ Di samping itu, tidak kurang daripada 22 buah hasil karya Nawawi masih tersebar secara meluas, manakala 11 buah kitab karyanya adalah termasuk dalam kumpulan 100 kitab yang paling banyak digunakan di pesantren. ${ }^{8}$ A.H Johns mendapati bahwa kesemua hasil karya beliau adalah dalam bahasa Arab yang sederhana. Hal ini mungkin karena ia sesuai dengan tahap kemampuan masyarakat Nusantara dalam memahami bahasa Arab, selain itu kitab-kitab beliau banyak digunakan di Nusantara. ${ }^{9}$ Karya-karya Sheikh Nawawi juga di pelajari disekolahsekolah agama Mindanou (Filipina Selatan) dan Thailand Selatan. Menurut Ray Salam T. Mangondaan, peneliti di Institute Studi Islam University of Philipines, karya Sheikh Nawawi banyak dipelajari di sekolah agama Filipina Selatan yang masih menggunakan sistim pembelajaran Tradisional ${ }^{10}$. Keunggulan Nawawi al-Bantani tidak hanya diakui di negaranya tetapi juga di dunia Arab. Dia dikenal melalui karyanya dalam bahasa Arab di pelbagai disiplin ilmu. Melalui karya-karyanya yang tersebar luas, maka nama Syeikh Nawawi termasuk dalam kategori ulama terkenal pada abad

\footnotetext{
${ }^{5}$ Ensiklopedia Islam,1994, cetakan ke-3, juz. 4,hlm. 24, Jakarta : PT, Ichtiar Baru Van Hoeve.

6 Ibid, hlm. 59-65.

7 Bruinesen, Martin Van, 1415/1995, Kitab Kuning (Pesantren dan Tarekat), terjemahan, hlm. 239, Bandung : Mizan.

$8 \mathrm{lbid}, \mathrm{hlm} 38$.

9 Johns, A.H t.th, Qur'anic Exegesis in the Malay Word, hlm. 3, t.pt, t.tp.

10 Agus Sutopo, 2008, Sumbangan Nawawi al-Bantani Dalam Bidang Hadis : Kajian Terhadap Kitab Tanqih al-Qawl, hlm. 53, Disertasi Majister. Jabatan al-Quran dan Hadis. Akademi Pengajian Islam, UM.
} 
14 H / 19 Masehi. Dia digelari sebagai al-Imam Muhaqqiq wa Fahmu Mudaqqiq dan digelari juga sebagai Imam Nawawi al-Tsani.11 Gelaran-gelaran lain yang diberikan kepada beliau ialah Ulama al-Hijaz, Imam ulama al-Haramayn, salah seorang Fuqaha' dan Hukama al-Mutaakhirin dan maha guru pada Nasrul Ma'arif Diniyyah di Makkah. ${ }^{12}$ Prof.Dr.Hamka menyebut bahawa Sheikh Nawawi merupakan tokoh ulama besar diawal abad ke empat belas hijrah atau dipenghujung abad ke tiga belas. K.H DR. Idham Chalid pernah memuji beliau dengan menyatakan : karangan Sheikh Nawawi[mencakupi seluruh bidang disiplin ilmu yang sangat diperlukan oleh ummat Islam (Indonesia). Oleh itu, beliau berhak mendapat gelaran pujangga dunia. ${ }^{13}$

\subsection{Pengenalan Kitab Nasa'ih al-'Ibad}

Kitab Nasa'ih al-'Ibad salah satu karya Sheikh Nawawi al-Banteni merupakan karya ilmiyah yang dikategorikan sebagai manuskrip kitab kuning dalam bidang keagamaan Islam. Keistimewaan kitab ini tidak hanya terletak pada kedudukannya sebagai kitab kuning yang bertuliskan bahasa Arab yang merupakan syarahan kepada kitab Munabbihat 'Ala al-Isti'dad li Yawm al-Ma'ad yang dikarang oleh Ibn Hajar al'Asqalani, malahan juga karena ia digunakan sebagai bahan rujukan bagi mendidik masyarakat Islam di Nusantara khususnya Indonesia serta mampu bertahan dalam jangka waktu yang begitu lama. Buktinya semenjak dihasilkan pada hari khamis 21 Safar tahun $1314 \mathrm{H}$ hingga kini, kitab ini masih disyarahkan dan diajar di masjid, surau, pondok pesantren dan halakah yang terdapat dipelosok Indonesia ${ }^{14}$. Kitab ini termasuk kategori kitab nasihat dan Targhib wa Tarhib yang berisikan nasihat-nasihat agama yang bersumber daripada al-Qur'an, hadith-hadith Nabi SAW, atsar para Sahabat dan kata-kata hikmah para hukama terkenal daripada pelbagai kalangan

\footnotetext{
11 Asnawi, 1989, Pemikiran Shaykh Nawawi Tentang Ayat Qada' dan Qadar Dalam Kitab Tafsirnya Marah Labib, hlm. 38, Tesis Sarjana, Jakarta : IAIN Syarif Hidayatullah.

12 Ensiklopedia Islam Indonesia, 1993, juz. 2, hlm. 845, Jakarta : Depdikbud Indonesia.

${ }^{13}$ Chaidar, 1978, Sejarah Pujangga Islam Shaykh Nawawi Banteni, hlm. Vi, Jakarta : CV Sarana Utama.

14 Muhammad Nawawi Banteni, t.th, Nasa'ih al-'Ibad Fi Bayan Alfaz Munabbihat 'Ala al-Isti'dad li Yaum al-Ma'ad, hlm. 80, Indonesia : Dar Ihta' al-Kutub al-'Arabiyyah.
} 
sama ada daripada ahli hadith, figh dan tasawuf. Kitab ini lebih banyak mengandungi hadith-hadith daripada Rasulullah SAW yang berjumlah lebih kurang 341 hadith baik ditulis dalam bentuk matan langsung ataupun ditulis dalam bentuk makna sahaja, dari pelbagai tingkat kesahihan hadith, dan berbagai bentuk kaedah penulisan hadithnya. Daripada 341 hadis, didapati 117 hadis Da'if dan 71 hadis Mawdu'.

\section{Hukum Beramal Dengan Hadis Da'if dan Mawdu'}

Sebagaimana hadis itu berbeza antara satu sama lain dari segi kekuatannya, oleh itu ada perbezaan dalam beramal dengan hadis, hadis Sahih dan Hasan merupakan hadis Maqbul yang diterima dalam pengambilan hukum, sedangkan hadis Da'if adalah hadis yang ditolak. Ulama berbeza pendapat dalam permasalahan ini, adakah hadis Da'if tidak diterima sebagai dalil dalam semua permasalahan atau sebahagian sahaja. Permasalahan itu boleh diringkas kepada 5 perkara :

\subsection{Hukum Beramal Dengan Hadis Daif Dalam Bidang Aqidah}

Majoriti ulama ijma' bahawa hadis Da'if tidak dapat digunakan sebagai dalil dalam permasalahan Aqidah seperti ma'rifah Allah, Malaikat, Qada' dan Qadar, permasalahan ghayb dan sebagainya. Bahkan sebahagian besar ulama mensyaratkan permasalahan Aqidah hanya boleh berhujah dengan hadis Mutawatir, adapun Ibn Qayyim dan ulama-ulama lain mengatakan bahawa Khabar Ahad yang Sahih boleh digunakan sebagai dalil dalam permasalahan Aqidah. ${ }^{15}$ Ini menunjukan bahawa dalam bidang Aqidah, hadis Da'if bukanlah merupakan sandaran hujah dikalangan semua ulama.

\subsection{Hukum Beramal Dengan Hadis Da'if Dalam Bidang Fada'il}

Para ulama berbeza pendapat adakah hadis Da'if boleh dijadikan hujjah dalam masalah Fada'il al-'Amal, Targhib (ajakan untuk mendapatkan pahala) dan Tarhib (ancaman mendapatkan dosa). Permasalahan ini sudah dibahas oleh para

\footnotetext{
${ }^{15}$ Abd al-Karim bin Abd Allah al-Khudayr, 1997 M, al-Hadith Da'if wa al-Hukm al-Ihtijaj Bihi, hlm. 249, Riyad : Dar al-Muslim.
} 
ulama sejak dulu lagi, masing-masing mempunyai hujah yang sangat kuat. Dalam makalah ini penulis akan cuba menghuraikannya dengan ringkas tanpa meninggalkan aspek-aspek penting yang terdapat dalam permasalah itu. Ini disebabkan kitab ini merupakan kitab nasihat yang di dalamnya terdapat banyak hadis tentang Targhib dan Tarhib. Perkara yang dimaksudkan oleh para ulama tentang hadis Da'if dalam permasalahan ini adalah hadis Da'if yang masih boleh dikuatkan oleh hadis yang lain (iaitu hadis yang di dalamnya terdapat perawi yang tidak dikenali atau Jahalah bi alRawidan tidak terdapat di dalamnya syarat Dabt al-Rawi seperti hadis Mursal, Mu'allaq, Mu'dal dan sebagainya. Adapun hadis yang sangat lemah kerana tohmahan terhadap 'Adalah Rawimaka dia bukanlah termasuk dalam pembahasan ini, seperti hadis , mawduk, Matruk, Munkar dan lain-lain. ${ }^{16}$ Pendapat ulama dalam permasalahan ini ada tiga iaitu :

1. Boleh Beramal Dengan Hadis Da'if

Diantara hujah yang dikemukakan oleh ulama yang membolehkan beramal dengan hadis Da'if dalam Fada'il al-'Amal secara mutlak adalah hadis yang diriwayatkan daripada Nabi SAW :

من بلغه عن الله فضل فأخذه بذلك الفضل أعطاه الله ما بلغه وان كان الذي حدثه كاذبا7 Maksudnya : Sesiapa yang sampai kepadanya keutamaan dari Allah SWT kemudian dia mengambil keutamaan tersebut maka Allah akan memberikan kepadanya apa yang telah dijanjikan walaupun orang yang menyampaikan hadis tersebut merupakan seorang pembohong. Hujah lain yang dikemukakan adalah bahawa hadis Da'if lebih kuat daripada pendapat ulama sebab ia dinisbahkan kepada Rasulullah SAW, pendapat ini dinisbahkan kepada beberapa orang ulama diantaranya : Muhammad bin al-Mu'in bin Muhammad al-Amin, al-Qadi Abu Bakar dan lain-lain. ${ }^{18}$

\footnotetext{
16 Umar bin Hasan al-Falatah, 1401 H, al-Wad'u Fi al-Hadith, jil. 3, hlm. 67-68, Dimasyk : Maktabah alGhazali.

17 Ibn Abd al-Bar, Yusuf bin Abd Allah, t.th, Jami' Bayan al-'Ilmi wa Fadlihi, hlm. 22, Mesir : Ummu alQura li al-Tiba'ah.

${ }_{18}$ Abd al-Karim bin Abd Allah al-Khudayr, 1997 M, al-Hadith Da'if wa al-Hukm al-Ihtijaj Bihi, hlm. 250260, Riyad : Dar al-Muslim.
} 


\section{Larangan Beramal Dengan Hadis Daif}

Hujjah yang dikemukakan diantaranya :

-Bilangan hadis Sahih yang sangat banyak dalam bidang Fada'il, Targhib dan Tarhib sudah mencukupi seorang muslim dalam pengamalan agamanya. Sewajarnya dia tidak perlu lagi mengambil hadis Da'if dalam masalah ini kerana ia termasuk sebahagiaan daripada tiang agama. ${ }^{19}$

-Hadis Da'if hanya memberikan faedah Zhan al-Marjuh (sangkaan yang tidak kuat) dan Rasul SAW mencela al-Dhan dalam salah satu hadisnya :

$$
\text { قال رسول الله صلى الله عليه وسلم : اياكم و الظن فان الظن أكذب الحديث20 }
$$

Maksudnya : Jauhilah sangkaan, sesunguhnya sangkaan adalah percakapan yang paling dusta.

Pendapat ini dinisbahkan kepada beberapa ulama diantaranya : Yahya bin Ma'in, alBukhari, Muslim, Ibn Hazm, Ibn al-'Arabi, Ibn Taymiyyah, al-Shawkani, Ahmad Muhammad Shakir dan al-Albani. ${ }^{21}$

3. Boleh Beramal Dengan Hadis Da'if Dengan Beberapa Syarat.

Pendapat ini adalah yang pertengahan dengan kedua-dua pendapat yang sebelumnya. Ini merupakan pendapat jumhur ulama bukannya kesepakatan ulama sebagaimana yang dikatakan oleh Imam Nawawi. Ini disebabkan ramai ulama besar yang tidak berpendapat seperti ini, sebagaimana yang telah disebutkan namanya dalam pendapat pertama dan kedua.

Terdapat 3 syarat yang dikemukakan oleh para ulama22 iaitu :

\footnotetext{
19 Umar bin Hasan al-Falatah, 1401 H, al-Wad'u Fi al-Hadith, jil. 3, hlm. 71, Dimasyk : Maktabah alGhazali.

20 al-Bukhari, Muhammad bin Isma'il, 1407H/1987M, Sahih al-Bukhari, Kitab : al-Birr, Bab : Ma Yunha An Tahasud Wa al-Tadabur, jil. 5, nh. 5717, hlm. 2253, Bayrut : Dar Ibn Kathir, Tahqiq : Mustafa Dib alBugha.

${ }^{21}$ Abd al-Karim bin Abd Allah al-Khudayr, 1997 M, al-Hadith Da'if Wa al-Hukm al-Ihtijaj Bihi, hlm. 262273, Riyad : Dar al-Muslim.

22 al-Tahanawi, Ahmad al-Uthmani, t.th, Qawa'id Fi 'Ulum al-Hadith, jil. 5, hlm. 94, Bayrut : Maktabah al-Matbu'ah al-Islamiyyah, Tahqiq : Abd al-Fattah Abu Ghuddah.
} 
a. Bukan merupakan hadis yang sangat Da'if. Dengan syarat ini, ertinya hadis yang diriwayatkan oleh al-Kadhdhabun (pendusta), al-Muttaham bil Kadhab (yang dituduh berdusta) dan perawi yang sangat banyak kesalahannya tidak dapat diterima haditnya, termasuklah di dalamnya hadis Mawdu'.

b. Hadis tersebut berada dalam landasan syarak yang di amalkan. Maksudnya ialah : hadis tersebut bersesuain maknanya dengan ayat al-Quran dan hadis yang Sahih.

c. Beramal degan hadis tersebut dengan niat memberi perhatian yang lebih agar mendapatkan keutamaan dan kelebihan. Maksudnya ialah : ketika beramal dengan hadis Da'if dalam permasalahan ini, bukanlah kerana kita meyakini bahawa hadis tersebut berasal daripada Rasul SAW, namun kerana kita berhati-hati dalam perkara agama, untuk mendapatkan pahala daripada hadis-hadis Targhib ataupun tidak mendapatkan dosa daripada hadis-hadis Tarhib. Sebahagian ulama menambahkan syarat-syarat lain selain daripada 3 syart ini, namun tidak di nyatakan di sini kerana sebahagian syarat tersebut sudah termasuk dalam 3 syarat di atas ataupun sudah sedia maklum yang tidak memerlukan penjelasan lagi seperti syarat tidak bertentangan dengan hadis yang Sahih.

Dalam permasalahan ini, penulis lebih menguatkan pendapat ketiga iaitu boleh beramal dengan hadis Da'if dengan 3 syarat dengan beberapa alasan :

a. Hadis yang digunakan oleh pendapat pertama sebagai dalil merupakan hadis Mawdu'.23

b. Dibolehkannya pengambilan hadis Da'if secara mutlak akan mengakibatkan tersebarnya bid'ah dan khurafat, kerana bid'ah dan khurafat banyak terdapat pada hadis yang sangat $D a$ iff.

c. Pendapat kedua yang berhujjah bahawa hadis Sahih sudah mencukupi dan tidak perlu lagi kepada hadis Da'if, ini memang suatu hal yang disepakati

${ }^{23}$ Muhammad Tahir al-Fattani al-Hindi, t.th, Tadhkirah al-Mawdu'at, hlm. 28, T.tp : T.pt. 
antara pendapat kedua dan ketiga kerana di antara syarat yang mereka sebutkan hadis tersebut berada dalam landasan syar'i yang dia amalkan,bukan merupakan suatu hukum yang baru yang berdiri sendiri.

d. Syarat beramal dengan niat intiyat (memberi perhatian yang lebih agar mendapatkan keutamaan dan kelebihan atau berhati-hati dalam mengerjakan ajaran agama) merupakan jawaban atas hujjah pendapat kedua yang mewajibkan pengambila hukum "harus dan sunat" daripada hadis yang Sahih, kerana hadis Da'if di sini hanya untuk ihktiyat sahaja, bukan sebagai pengambilan hukum.

\subsection{Hukum Beramal Dengan Hadis Da'if Dalam Bidang Ahkam}

Ulama berbeza pendapat adakah hadis Da'if boleh dijadikan hujjah dalam ahkam seperti penentuan halal dan haram atau sesuatu perkara itu wajib, sunat, harus, makruh dan haram. Perkara yang dimaksudkan oleh para ulama tentang hadis Da'if dalam permasalahan ini adalah hadis Da'if yang masih boleh dikuatkan oleh hadis Da'if yang lain seperti perbahasan pada bab fada'il. Dalam permasalahan ini terapat dua pendapat ulama iaitu :

1. Boleh beramal dengan hadis Da'if dalam masalah Ahkam.

Diantara hujjah yang dikemukakan adalah hadis Da'if merupakan sesuatu yang disandarkan kepada Nabi SAW. la lebih kuat daripada qiyas dan pendapat para ulama dari kalangan ahli fiqh. ${ }^{24}$ Di samping itu tidak terdapat hadis Sahih yang bertentangan dengannya dan tidak terdapat hadis lain dalam bab tersebut selain daripadanya. ${ }^{25}$ Pendapat ini dinisbahkan kepada beberapa orang ulam di antaranya : Imam Abu Hanifah, Imam Malik, Imam Ahmad, Imam al-Nasa'i, Imam Abu Daud dan lain-lain.

\footnotetext{
${ }^{24}$ al-Tahanawi, Ahmad al-Uthmani, t.th, Qawa'id Fi 'Ulum al-Hadith, jil. 5, hlm. 92, Bayrut : Maktabah al-Matbu'ah al-Islamiyyah, Tahqiq : Abd al-Fattah Abu Ghuddah.

${ }^{25}$ Abd al-Karim bin Abd Allah al-Khudayr, 1997 M, al-Hadith Da'if wa al-Hukm al-lhtijaj Bihi, hlm. 250, Riyad : Dar al-Muslim.
} 
2. Tidak boleh beramal dengan hadis Da'if dalam masalah Ahkam. Diantara hujjah yang dikemukakan adalah :

- Bilangan hadis Sahih yang sangat banyak dalam bidang ahkam sudah mencukupi seorang muslim dalam pengamalan agamanya. Sewajarnya dia tidak perlu lagi mengambil hadis Da'if dalam masalah ini. ${ }^{26}$

- Harus dan sunat termasuk dalam hukum syarak yang lima iaitu wajib, sunat, harus, makruh dan haram. Kelima-lima hukum ini mestilah ditetapkan dengan hadis yang Sahih bukan dengan hadis yang Da'if.

- Hadis Da'if hanya memberikan faedah Dhan al-Marjuh (sangkaan yang tidak kuat) sahaja sedangkan Allah Ta'ala mencela Dhan.

Dalam masalah ini penulis lebih menguatkan pendapat kedua yang menyatakan bahawa tidak boleh beramal degan hadis Da'if dalam masalah ahkam, alasannya ialah:

- Hadis yang Sahih sangatlah banyak dan sudah mencukupi bagi seorang muslim dalam mengamalkan ajaran agamanya.

- Hukum syarak mesti ditetapkan dengan hadis yang Sahih bukan dengan hadis yang Da'if.

- Pendapat pertama yang dinisbahkan kepada beberapa ahli fikh, bukanlah nas perkataan mereka, namun ini diambil dari perhatian terhadap kitab-kitab karangan mereka.

- Adapun hadis-hadis yang mereka ambil sebagai hujjah bukanlah hadis yang bersangatan lemahnya sehingga tidaklah dapat dikatakan mereka menerima hadis Da'if secara mutlak, akan tetapi mereka mengambil hadis-hadis Da'if yang masih boleh naik menjadi hadis Hasan Lighayrih.

\footnotetext{
${ }^{26}$ Umar bin Hasan al-Falatah, 1401 H, al-Wad'u Fi al-Hadith, jil. 3, hlm. 71, Dimasyk : Maktabah alGhazali.
} 


\subsection{Hukum Beramal Dengan Hadis Da'if Dalam Bidang Tafsir dan Qira'at}

Semua ulama sepakat bahawa hadis Daiff tidak boleh dijadikan dalil dalam menafsirkan al-Quran dan dalam pengambilan qiraatnya. Ibn 'Allan berakata : mentafsirkan al-Quran tidak boleh kecuali dengan hadis Sahih dan Hasan ${ }^{27}$. Shaikh Muhammad Husayn Dhahabi berkata : adapun tafsir al-Quran dengan al-Quran atau dengan sunnah yang Sahih, semua itu tidak ada khilaf dalam penerimaannya kerana tidak ada kelemahan dan tidak ada keraguan sedikitpun di dalamnya. Adapun yang dinisbakah kepada Nabi SAW, dan terdapat kelemahan dalam sanad dan matannya, maka itu ditolak tidak diterima sedikitpun dan tidak benarlah nisbahnya kepad Nabi SAW.28 Adapun wujudnya riwayat Isra'liyyat dalam kitab-ktab tafsir, bukanlah merupakan suatu keizinan dari pengarangnya terhadap bolehnya pengambilan hadis Da'if dan Isra'lilyyat sebab para ulama ahli tafsir sudah menerangkan dalam muqaddimah kitabnya tentang hukum tersebut seperti Ibn Kathir dan Ibn 'Atiyyah. Dan dalam pengambilan qiraah al-Quran permasalahannya sudah jelas kerana perbezaan yang terjadi antara ulama : apakah hadis Ahad yang Sahih boleh digunakan dalam menentukan qiraah ataukah hanya hadis Mutawatir? Kalaulah hadis Ahad Sahih masih terdapat perbezaan dalam penerimaannya apatah lagi hadis yang Da'if.

\subsection{Hukum Beramal Dengan Hadis Da'if Dalam Bidang al-Siyar (sejarah hidup Rasulullah) dan al-Maghazi (sejarah peperangan Nabi SAW)}

Kebanyakan ulama tidak memperketat penerimaan hadis dalam bidang Siyar dan al-Maghazi, dan mereka hanya mensyaratkan agar ulama tarikh tersebut seorang yang 'Adil dan Benar, sehingga dia dapat membezakan riwayat tarikh yang benar dan riwayat yang salah. Imam Ahmad berkata : Ibn Ishaq seorang yang ditulis hadisnya dalam sirah, maghazi dan lainnya dan ketika datang permasalahan halal dan haram,

\footnotetext{
27 Muhammad Allan al-Siddiqi, 1347 H, al-Futuhat al-Rabbaniyah 'Ala Azkar al-Nawawiyah, jil. 1, hlm. 86, Mesir : Matba'ah Sa'adah.

28 Muhammad Husayn al-Dhahabi, 1381H, Tafsir al-Muffasirun, jil : 1, hlm. 156, T.tp : Matba'ah Dar alKutub al-Hadithah.
} 
maka yang kami inginkan perawi yang seperti ini kemudian beliau mengepalkan jarijari tangan beliau ${ }^{29}$ (maksudnya perawi yang Thiqqah). Untuk beramal dengan hadishadis Mawdu' sudah disepakati bahawa ianya terlarang dan tidak dibenarkan sebab sudah jelas kedustaan yang di ada-adakan kepada Nabi SAW. Wallahu A'lam.

\section{Metodologi kajian}

Kajian artikel ini menggunakan metodologi kualitatif. Pendekatan metode kepustakaan digunakan untuk menganalisis hasil karya Sheikh Nawawi al-Bantani terutama berkaitan analisis terhadap hadis-hadis yang terdapat dalam kitab Nasa'ih al-'Ibad. Pengumpulan data adalah metode yang paling umum untuk mendapatkan data atau fakta yang berkaitan dengan subjek kajian ini. Sumber primer kajian ini adalah kitab Nasaihh al-'Ibad hasil penulisan Sheikh Nawawi al-Bantani sendiri. Manakala sumber sekunder pula ialah merujuk kepada buku-buku, jurnal, majalah, makalah-makalah serta sumber lain yang berkaitan.

\subsection{Skop Kajian}

Dalam kitab Nasa'ih al-'Ibad terdapat 341 hadis bermula dari bab 1-10, daripada kesemua hadis tersebut, ianya mengandungi pelbagai hukum dan kedudukan hadis sama ada Sahih, Hasan, Da'if, Da'if Jiddan, Mawdu' dan bahkan ada yang tidak ditemui sumbernya. Namun di sini penulis hanya memfokuskan 236 hadis mulai dari bab 5-10.

\section{Hasil dan Perbincangan}

Dalam kitab Nasa'ih al-'Ibad mulai dari bab 1-10 terdapat 341 hadis, daripada jumlah tersebut terdapat pelbagai hukum dan kedudukan hadis sama ada Sahih, Hasan, Da'if, Da'if Jiddan, Mawdu'dan bahkan ada yang tidak dikesan sumbernya sama sekali. Setelah dibuat kajian maka didapati semua hadis Da'if yang terdapat dalam kitab Nasa'ih al-'Ibad ini adalah 117 hadis Da'if atau sekitar 34\% dan 71 hadis

\footnotetext{
${ }^{29}$ Abd al-Karim bin Abd Allah al-Khudayr, 1997 M, al-Hadith Da'if wa al-Hukm al-Ihtijaj Bihi, hlm. 320, Riyad : Dar al-Muslim.
} 
Mawdu' atau sekitar 21\%. Namun dalam kajian ini penulis hanya fokuskan kepada bab 5-10 saja dan hadisnya berjumlah 236 hadis. Majoriti hadis dalam kitab tersebut lebih menitik beratkan kepada hadis-hadis berisikan nasihat atau Targhib wa Tarhib. Selain itu didapati juga hadis-hadis yang mengandungi amalan sehari-hari. Di sini penulis ingin menghuraikan beberapa bentuk hadis Da'if dan Mawdu' yang dijadikan sebagai amalan keseharian masyarakat yang terdapat dalam kitab Nasa'ih al-'Ibad. Antaranya

$$
\text { 1). قال صلى الله عليه وسلم : من توضأ على طهر كتب له عشر حسنات. }
$$

Maksudnya : Nabi SAW bersabda : barang siapa berwuduk dalam keadaan masih suci maka dicatat untuknya sepuluh kebaikan. Hadis ini diriwayatkan oleh Abi Dawud dalam Sunannya ${ }^{30}$, al-Tirmidhi dalam Sunannya ${ }^{31}$, Ibn Majah dalam Sunannya ${ }^{32}$ dan al-Bayhaqi dalam Sunan al-Kubra 33 semuanya menerusi 'Abd Allah bin 'Umar. Hadis ini adalah da'if disebabkan terdapat perawi bernama Abu Ghatif alHazali. Imam Tirmidhi mengatakan bahawa dia Majhul dan Imam al-Bukhari pula mengakatan bahawa dia La Yutbi' Alahi34 dan 'Abd al-Rahman bin Ziyad al-Muqri', beliau di Da'ifkan oleh Yahya bin Ma'in, al-Nasa'i dan Ibn Adi35.

\footnotetext{
${ }^{30}$ Abi Dawud, Sulayman bin al-Ash'ash, 1420/1999, Sunan Abi Dawud, Kitab : al-Taharah, Bab : alRajuli Yujaddid al-Wudu' Min Ghayri hadath, $\mathrm{n}$ h : 62, jil. 1, hlm. 37, al-Qahirah : Dar al-Hadith, Tahqiq : Abd al-Qadir Abd al-Khayr \& Sayyid Muhmmad Sayid.

${ }^{31}$ al-Tirmidhi, Abu Isa Muhammad Ibn Isa Ibn Sawrah, 1419/1999, Sunan Tirmidhi, Kitab : al-Taharah, Bab : Ma Ja'a Fi al-Wudu' Li Kulli Salat, n h : 59, jil. 1, hlm. 152, al-Qahirah : Dar al-Hadith, Tahqiq : Doktor Mustafa Muhammad Hussayn al-Dhahabi.

32 Ibn Majah, Abu Abd Allah Muhammad Ibn Yazid al-Qazwayni, 1419/1998, Sunan Ibn Majah, Kitab : al-Taharah, Bab : al-Wudu' 'Ala Taharah, n h : 512, jil. 1, hlm. 219, al-Qahirah : Dar al-Hadith, Tahqiq : Muhammad Fu'ad Abd al-Baqi.

33 al-Bayhaqi, Abu Bakar Ahmad bin al-Husayn bin Ali al-Bayhaqi, 1420/1999, Sunan al-Kubra, Kitab : al-Taharah, Bab : Tajdid al-Wudu', n h : 762, jil. 1, hlm. 251, Bayrut : Dar al-Qutub al-Ilmiyyah, Tahqiq : Mustafa Abd al-Qadir Ata.

34 al-Tirmidhi, Abu Isa Muhammad Ibn Isa Ibn Sawrah, 1419/1999, Sunan Tirmidhi, Kitab : al-Taharah, Bab : Ma Ja'a Fi al-Wudu' Li Kulli Salat, n h : 59, jil. 1, hlm. 152, al-Qahirah : Dar al-Hadith, Tahqiq : Doktor Mustafa Muhammad Hussayn al-Dhahabi.

35 al-Dhahabi, Mizan al-l'tidal Fi Naqd al-Rijal, no : 4866, jil. 3, hlm. 275-276.
} 


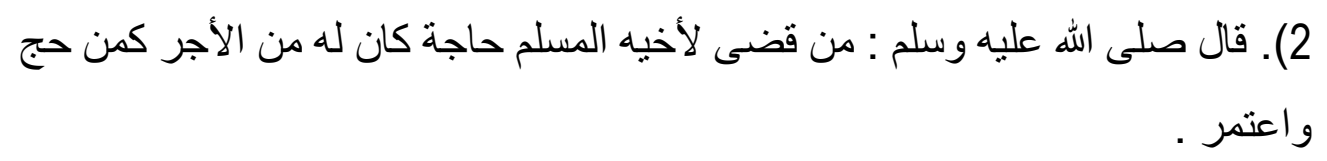

Maksudnya : Nabi SAW bersabda : barang siapa yang memenuhi keperluan saudaranya yang muslim, maka baginya pahala seperti orang yang berhaji dan berumrah. Hadis ini diriwayatkan oleh Abu Nu'aym dalam Hilyah ${ }^{36}$, al-Khatib alBaghdai dalam Tarikh Baghdad ${ }^{37}$ menerusi Anas bin Malik. Hadis ini adalah Mawdu' disebabkan sanad hadisnya adalah Da'if Musalsal daripada Jemaah kelompok Sufi yang tidak dikenal (Majhul) antaranya adalah Nawri, al-Siqti¿dan al-Kurkhi. Kemudian hadis ini pula Munqati' (terputusnya sanad) antara A'mash dan Anas bin Malik kerana tidak Thabit pendengaran A'mash daripada Anas bin Malik. al-Munawi mengatakan bahawa hadis ini adalah palsu kerana terdapat tiga ahli Sufi yang tidak aku kenal iaitu Nawri, al-Siqtiddan al-Kurkhi38. Albani juga mengatakan bahawa hadis ini adalah Mawdu' dalam Silsilah Ahadit Da'ifah wa al-Mawdu'ah ${ }^{39}$. Wallahu A'lam.

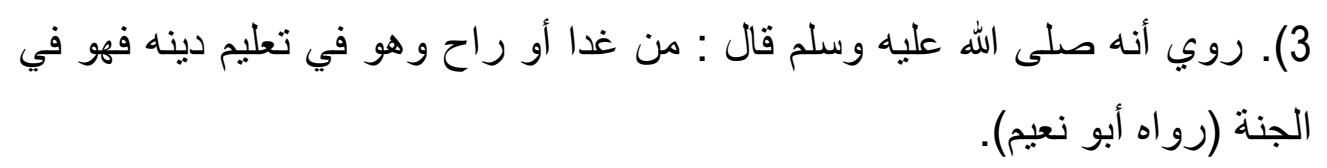

Maksudnya : Diriwayatkan bahawa Nabi SAW bersabda : barang siapa bangun pagi-pagi mengajarkan ilmu agamanya, maka ia akan masuk syurga (diriwayatkan oleh Abu Nu'aym). Hadis ini diriwayatkan oleh Abu Nu'aym dalam alHilyah 40 melalui Abu Sa'id al-Khudri. Hadis ini Mawdu' disebabkan terdapat perawi Isma'il bin Yayha al-Taymi dan dia adalah pemalsu hadis dan Kadhahab. Salih bin Muhammad Jazarah mengatakan bahawa dia pemalsu hadis, Ibn 'Adi mengatakan

\footnotetext{
${ }^{36}$ Abu Nu'aym al-Asfahani, Ahmad Ibn Abd Allah, 1988, Hilyah al-Awliya' wa Tabaqat al-Asfiya', jil. 10, hlm. 254-255, bayrut : dar al-kutub al-ilmiyyah.

${ }^{37}$ al-khatib al-Baghdadi, Ahmad bin Ali al-Khatib al-Baghdadi,1417/1997, Tarikhh Bagdad, jil. 5, hlm. 338-339., Bayrut : Dar al-Qutub al-IImiyyah, Tahqiq : Mustafa Abd al-Qadir Ata.

38 al-Munawi, Muhamamd Ibn Abd al-Ra'uf, 1356/ 1938, Fayd al-Qadir Sharah Jami' al-Saghir, jil. 6, hlm. 205, Misr : Matba'at Mustafa Muhammad.

39 al-Albani, Silsilah Ahadith Da'ifah wa al-Mawdu'ah, n h : 753, jil. 2, hlm. 174-175.

40 Abu Nu'aym al-Asfahani, Ahmad Ibn Abd Allah, 1988, Hilyah al-Awliya' wa Tabaqat al-Asfiya', jil. 7 , hlm. 251, Bayrut : Dar al-Kutub al-Ilmiyyah.
} 
bahawa hadis yang diriwayatkannya ini adalah batil dan palsu, al-Azadi, Dar alQutni[dan al-Hakim mengatakan bahawa dia adalah Kadhdhab, dan al-Dhahabi pula mengatakan bahawa ulama sepakat untuk meninggalkannya ${ }^{41}$. al-Albani[juga menghukum hadis ini Mawdu' dalam Silsilah Ahadis Da'if wa al-Mawdu'ah42.

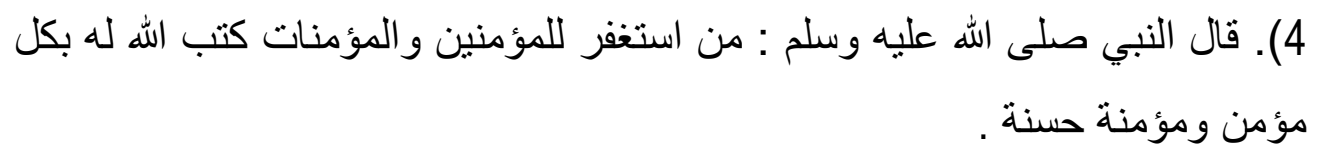

Maksudnya : Nabi SAW bersabda : barang siapa yang memohon ampunan bagi orang mukmin dan mukminat, nescaya Allah mencatatkan baginya kebaikan setiap orang mukmin dan mukminat. Hadis ini diriwayatkan oleh al-tabarani dalam Musnad al-Shamiyyin ${ }^{43}$, daripada 'Ubadah bin Samit. Hadis ini Da'if sebab terdapat perawi yang cacat kedudukannya, di antaranya ialah Bakar bin Khunays. Ibn Ma'in, alNasa'i dan Abu hatim menDa'ifkannya ${ }^{44}$. Perawi yang kedua 'Utbah bin Humayd, Abu Hatim mengatakan bahawa dia Salih sedangkan Ahmad mengatakan bahawa dia Da'if dan tidak Qawwi45. Perawi selanjutnya adalah Isa bin Sinan dan dia adalah seorang yang Da'if dan Layyin sepertimana yang dikatakan oleh Ahmad, Ibn Ma'in dan Abu Hatim $^{46}$. Hadis ini juga diDa'ifkan oleh al-Suyuti sebagaimana disebutkan oleh alMunawi dalam Fayd al-Qadir47.

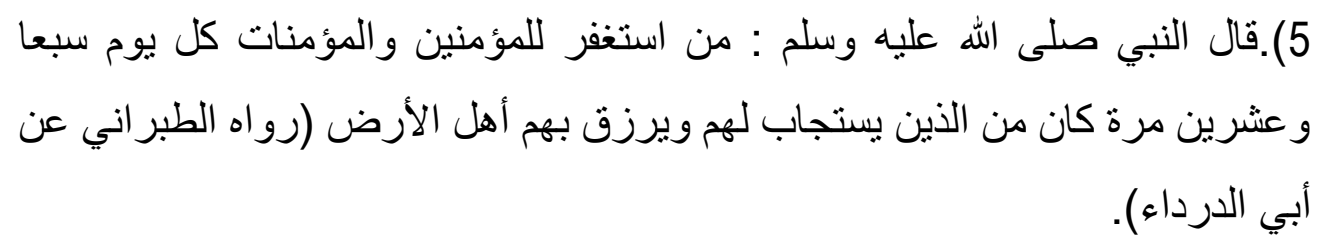

\footnotetext{
${ }^{41}$ al-Dhahabi, Mizan al-l'tidal Fi Naqd al-Rijal, no : 965, jil. 1, hlm. 253.

42 al-Albani, Silsilah Ahadit Da'if wa al-Mawdu'ah, n h : 4624, jil. 10, hlm. 138-139.

43 al-Tabarani, Sulayman bin Ahmad bin Ayyub al-Tabarani, 1409 H/1989M, Musnad al-Shamiyyin, $\mathrm{n} \mathrm{h}$ : 2155, jil. 3, hlm. 234, Bayrut : Mu'assasah al-Risaalh, Tahqiq : Hamdi 'Abd al-Majid al-Salafi.

44 al-Dhahabi, Mizan al-l'tidal fi Naqd al-Rijal, no : 1279, jil. 1, hlm. 344.

45 al-Dhahabi, Mizan al-l'tidal fi Naqd al-Rijal, no : 5470, jil. 3, hlm. 425.

${ }^{46}$ al-Dhahabi, Mizan al-l'tidal fi Naqd al-Rijal, no : 6568, jil. 4, hlm. 232.

47 al-Munawi, Fayd al-Qadir Sharah Jami' Saghir, n h : 8419, jil : 6, hlm. 57.
} 
Maksudnya : Nabi SAW bersabda : barang siapa yang memohon ampunan bagi orang-orang mukmin dan mukminat setiap hari sebanyak 27 kali, maka orang tersebut termasuk orang yang dikabulkan doanya dan menjadi penyebab turunnya rezeki kepada penduduk bumi (diriwayatkan oleh al-Tabarani daripada Abi Darda'). Hadis ini diriwayatkan oleh al-Tabarani dalam Mu'jam al-Kabir ${ }^{48}$ daripada Abu Darda'. Haythami mengatakan bahawa hukum hadis ini adalah Da'if Jiddan kerana perawinya bernama Uthman Ibn Abi 'Atikah diDa'ifkan oleh jumhur ulama49. al-Shawkani mengatakan dalam Tuhfaat al-Zakirinnya bahawa dia Da'if Jiddan dan Munkar50. Hadis ini juga dilemahkan oleh al-Suyuti, sebagaimana disebutkan oleh al-Munawi』dalam Fayd al-Qadirnya ${ }^{51}$.

Tabel 1 : Hasil Kajian Hadis-Hadis Da'if, Da'if Jiddan dan Mawdu' Dalam Kitab Nasa'ih al-'Ibad Mulai Bab 5-10.

\begin{tabular}{cccc}
\hline Bab & \multicolumn{3}{c}{ Hukum Hadis } \\
\cline { 2 - 4 } & Da'if & Da'if Jiddan & Mawdu' \\
\hline 5 & 6 & 0 & 9 \\
6 & 14 & 2 & 16 \\
7 & 6 & 2 & 6 \\
8 & 6 & 2 & 8 \\
9 & 0 & 0 & 3 \\
10 & 36 & 16 & 23 \\
Jumlah & 68 & 22 & 65 \\
Persen (\%) & 28.8 & 9.3 & 27.5 \\
\hline
\end{tabular}

\footnotetext{
48 al-Tabarani, Abu al-Qasim Sulayman Ibn Ahmad, t.th, Mu'jam al-Kabir, n h : 407, jil. 19, hlm. 180, t.tp : Dar al-Ma'rifah, Tahqiq : Hamdi Abd al-Majid al-Salafi.

49 al-Haythami, Nur al-Din Ali bin Abi Bakar al-Haythami, 1414/1994, Majma' Zawa'id wa Manba' alFawa'id, Kitab : al-Tawbah, Bab : Istighfar li al-Mukmin wa al-Mukminat, jil. 10, hlm. 210, al-Qahirah : Maktabah al-Qudsi.

50 al-Shaukani, Muhammad bin 'Ali bin Muhammad al-Shaukani, tth, Tuhfah al-Dhakirin, Bab : alIstighfar, hlm. 256, Bayrut : Maktabah al-Thaqafiyah.

51 al-Munawi, Fayd al-Qadir Sharah jami' saghir, n h : 8419, jil. 6, hlm. 57.
} 
Syeikh Nawawi al-Banteni sebagai salah seorang ulama yang masyhur pada masanya mempunyai karya-karya amat bermutu dan tinggi nilainya. Di antaranya ialah kitab Nasa'ih al-'Ibad yang menjadi sumbangan beliau bagi masyarakat dan kalangan pelajar agama sehingga senantiasa menjadi bahan bacaan dan rujukan hingga ke hari ini. Kitab ini bukan sekedar masyhur sebagai bahan bacaan dan rujukan saja, tetapi di dalamnya mengandungi banyak hadis-hadis Nabi SAW. Selain itu ada juga atsar sahabat, kata-kata hikmah, sya'ir-sya'ir Arab dan hikayat. Berbicara tentang hadis tentunya kita tidak terlepas daripada hukum hadis baik itu yang Sahih, Hasan, Daif, Da'if Jiddan maupun Mawdu'. Hadis Sahih dan Hasan sudah tentu boleh dijadikan hujjah baik itu hujjah untuk akidah mahupun ibadah. Sedangkan hadis Da'if, Da'if Jiddan dan Mawdu' merupakan hadis Mardud yaitu hadis yang tertolak, tertolak untuk berhujjah dari segi akidah, namun ada sebagiaannya boleh dijadikan hujjah dalam Fada'il al-Amal apabila telah memenuhi syarat-syarat yang telah ditetapkan oleh para ulama. Oleh itu dalam kajian ini penulis mengkaji sebanyak 236 hadis bermula dari bab 5 hingga bab 10, didapati 68 hadis Da'if (28.8 \%), 22 hadis Da'if Jiddan (9.3\%) dan 65 hadis Mawdu' (27.5\%). Disimpulkan, bahwa hampir 50 \% hadis-hadis Da'if dan Mawdu' yang terdapat dalam bab 5-10 yang tidak boleh dijadikan sandaran hukum dan rujukan karena status hadisnya yang tertolak. Hanya $23.0 \%$ yang dapat dijadikan sandaran dalam Fada'il al-Amal jika sekiranya telah memenuhi syarat-syarat yang ditentukan oleh para ulama seperti yang penulis dijelaskan di atas.

\section{Kesimpulan}

Setelah menganalisa kitab Nasa'ih al-'lbad ini ianya bermula dari bab 5-10, dapat disimpulkan bahwa kitab Nasa'ih al-'Ibad mengandungi hadis Sahih dan Hasan yang dapat dijadikan Hujjah dalam amalan. Selain itu, terdapat juga hadis Da'if, Da'if Jiddan (sangat Da'if), Mawdu' bahkan ada yang tidak ditemukan sumber aslinya. Jumlah hadis Da'if dan Mawdu' dalam kitab ini lebih banyak daripada hadis Sahih dan 
Hasan. Selain itu dalam kajian ini, penulis lebih memfokuskan kepada hadis Da'if, Da'if Jiddan dan Mawdu'.

\section{Rujukan}

Abd al-Karim bin Abd Allah al-Khudayr. 1997. al-Hadis Da'if wa al-Hukm al-Ihtijaj Bihi. Riyad : Dar al-Muslim.

Abi Dawud, Sulayman bin al-Ash'ash. 1420/1999. Sunan Abi Dawud. al-Qahirah : Dar al-Hadis, Tahqiq : Abd al-Qadir Abd al-Khayr \& Sayyid Muhmmad Sayid.

Abu Nu'aym al-Asfahani, Ahmad Ibn Abd Allah. 1988. Hilyah al-Awliya' wa Tabaqat alAsfiya'. Bayrut : Dar al-Kutub al-Ilmiyyah.

Agus Sutopo. 2008. Sumbangan Nawawi al-Bantani Dalam Bidang Hadis : Kajian

Terhadap Kitab Tanqih al-Qawl. Disertasi Majister, Jabatan al-Quran dan Hadis, Universiti Malaya.

al-Albani, Muhammad Nasr al-Din. 1420/2000. Silsilah Ahadis Da'ifah wa alMawdu'ah, Riyad : Maktabah al-Maarif.

al-Bantani, Muhammad Nawawi. t.th. Nasa'ih al-'Ibad Fi Bayan Alfaz Munabbihat 'Ala al-Isti'dad li Yaum al-Ma'ad. Indonesia : Dar Ihta' al-Kutub al-'Arabiyah.

al-Bayhaqi, Abu Bakar Ahmad bin al-Husayn bin Ali al-Bayhaqi. 1420/1999. Sunan alKubra. Bayrut : Dar al-Qutub al-IImiyyah, Tahqiq : Mustafa Abd al-Qadir Ata.

al-Tabarani, Abu al-Qasim Sulaiman Ibn Ahmad. t.th. Mu'jam al-Kabir. t.tp : Dar alMa'rifah, Tahqiq : Hamdi Abd al-Majid al-Salafi.

al-Tabarani, Sulayman bin Ahmad bin Ayyub al-Tabarani. 1409 H/1989M. Musnad alShamiyyin, Bayrut : Mu'assasah al-Risalah, Tahqiq : Hamdi 'Abd al-Majid alSalafi.

al-Tahanawi, Ahmad al-Uthmani. t.th. Qawa'id Fi 'Ulum al-Hadis. Bayrut : Maktabah al-Matbu'ah al-Islamiyyah, Tahqiq : Abd al-Fattah Abu Ghuddah.

al-Tirmidhi, Abu Isa Muhammad Ibn Isa Ibn Sawrah. 1419/1999. Sunan Tirmidhi. alQahirah : Dar al-Hadis, Tahqiq : Doktor Mustafa Muhammad Hussayn alDhahabi.

Asnawi. 1989. Pemikiran Sheikh Nawawi Tentang Ayat Qada' dan Qadar Dalam Kitab Tafsirnya Marah Labib. Jakarta : IAIN Syarif Hidayatullah.

Bruinesen, Martin Van. 1415/1995. Kitab Kuning (Pesantren dan Tarekat). Bandung : Mizan.

al-Bukhari, Muhammad bin Isma'il. 1407H/1987M. Sahih al-Bukhari. Bayrut : Dar Ibn Kathir, Tahqiq : Mustafa Dib al-Bugha.

Chaidar. 1978. Sejarah Pujangga Islam Syaikh Nawawi Banteni. Jakarta : CV Sarana Utama.

al-Dhahabi, Muhammad Ibn Ahmad Ibn Uthman. 1416/1995. Mizan al-l'tidal Fi Naqd al-Rijal. Bayrut : Dar al-Qutub al-Ilmiyyah, Tahqiq : Ali Muhammad alMu'awwad. 
Ensiklopedia Islam. 1994. Jakarta : PT Ichtiar Baru Van Hoeve.

Ensiklopedia Islam Indonesia. 1993. Jakarta : Depdikbud Indonesia.

al-Haythami, Nur al-Din Ali bin Abi Bakar al-Haythami. 1414/1994. Majma' Zawa'id Wa Manba' al-Fawai'id. al-Qahirah : Maktabah al-Qudsi.

Ibn Abd al-Bar, Yusuf bin Abd Allah. t.th. Jami' Bayan al-'IImi wa Fadlihi. Mesir : Ummu al-Qura li al-Tiba'ah.

Ibn Majah, Abu Abd Allah Muhammad Ibn Yazid al-Qazwayni. 1419/1998. Sunan Ibn Majah. al-Qahirah : Dar al-Hadis, Tahqiq : Muhammad Fu'ad Abd al-Baqi.

Johns, A.H. t.th. Qur'anic Exegesis in the Malay Word, t.tp : t.pt.

Karel, S.A. 1984. Beberapa Aspek Tentang Islam di Indonesia Abad ke 19. Jakarta : Terjemahan Bulan Bintang.

al-Khatib al-Baghdadi, Ahmad bin Ali al-Khatib al-Baghdadi. 1417/1997. Tarikhh Bagdad. Bayrut : Dar al-Qutub al-IImiyyah, Tahqiq : Mustafa Abd al-Qadir Ata. Muhammad Tahir al-Fattani al-Hindi. t.th. Tadhkirah al-Mawdu'at. T.tp : T.pt.

Muhammad Allan al-Siddiqi. $1347 \mathrm{H}$. al-Futuhat al-Rabbaniyah 'Ala Azkar alNawawiyah. Mesir : Matba'ah Sa'adah.

Muhammad Husayn al-Dhahabi. 1381 H. Tafsir al-Muffasirun. T.tp : Matba'ah Dar alKutub al-Hadisah.

al-Munawi, Muhamamd Ibn Abd al-Ra'uf. 1356/ 1938. Fayd al-Qadir Sharah Jami' alSaghir. Misr : Matba'at Mustafa Muhammad.

Rafi'uddin Ramli, H. t.th. Sejarah Hidup dan Silsilah Keturunan Sheikh Nawawi Banteni. Banten : Yayasan Nawawi Tanara.

Sarkis, Yusuf 'Allan. t.th. Mu'jam al-Matbu'ah al-'Arabiyyah wa al-Mu'arrabah. alQahirah : Maktabah al-Thaqafah al-Diniyyah.

al-Shaukani, Muhammad bin 'Ali bin Muhammad al-Shaukani. T.th. Tuhfah al-Dhakirin. Bayrut : Maktabah al-Thaqafiyah.

Umar Ibn Hasan al-Falatah. 1401 H. al-Wad'u Fi al-Hadis. Dimasyk : Maktabah alGhazali. 